Cornell University Law School Scholarship@Cornell Law: A Digital Repository

Fall 2016

\title{
Legitimacy and Impartiality as Basic Principles for Sovereign Debt Restructuring
}

Odette Lienau

Cornell Law School, o153@cornell.edu

Follow this and additional works at: http://scholarship.law.cornell.edu/facpub

Part of the Banking and Finance Law Commons

\section{Recommended Citation}

Odette Lienau, "Legitimacy and Impartiality as Basic Principles for Sovereign Debt Restructuring," 41 Yale Journal of International Law Online (2016)

This Article is brought to you for free and open access by the Faculty Scholarship at Scholarship@Cornell Law: A Digital Repository. It has been accepted for inclusion in Cornell Law Faculty Publications by an authorized administrator of Scholarship@Cornell Law: A Digital Repository. For more information, please contact jmp8@cornell.edu. 


\title{
Legitimacy and Impartiality as Basic Principles for Sovereign Debt Restructuring
}

\author{
Odette Lienau*
}

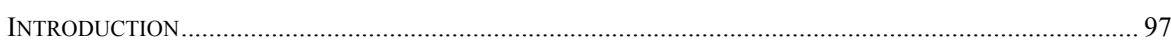 \\ I. THE INSTRUMENTAL VALUE OF LEGITIMACY AND IMPARTIALITY.......................................................... 98

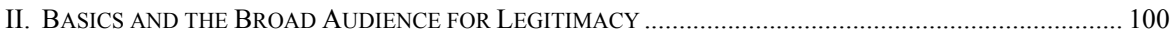

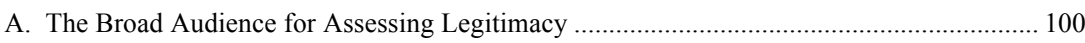 \\ B. Components of Legitimacy: Source, Process, and Outcome ……………………................. 101

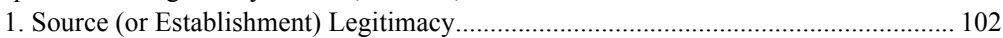 \\ 2. Process (or Implementation) Legitimacy .................................................................. 103 \\ 3. Outcome or Substantive Legitimacy........................................................................ 106

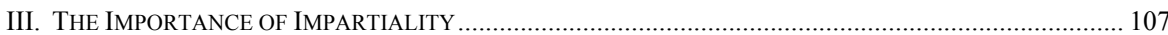

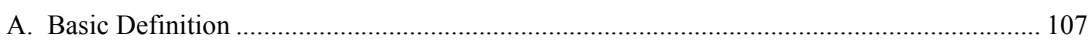

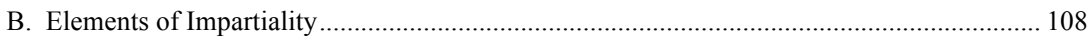 \\ IV. FOUNDATIONS IN DOMESTIC INSOLVENCY PRINCIPLES.............................................................. 109

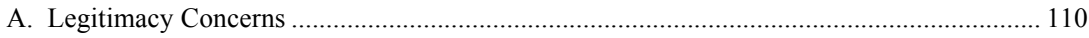

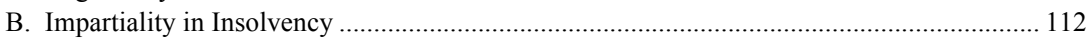 \\ V. EFFORTS TOWARD IMPARTIALITY AND LEGITIMACY IN INVESTOR TREATY ARBITRATION............... 113

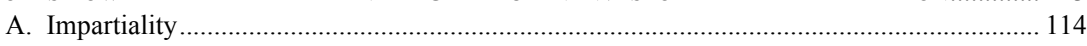

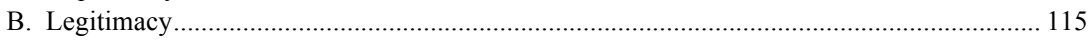

CONCLUSION

116

\section{INTRODUCTION}

The ongoing debt difficulties faced by multiple countries across the globe highlight the pressing need to improve sovereign debt restructuring practices. Major international institutions have recognized this need-the International Monetary Fund (IMF) has undertaken a review of its practices in this arena; the United Nations Conference on Trade and Development (UNCTAD) has engaged in extensive discussions with a view to bettering the current system; and the UN General Assembly addressed the topic through important resolutions in each of the last two years.

In light of this recent activity, this special issue of YJIL Online is especially timely, as it focuses on the applicability and ramifications of the "incremental approach" advocated by the UN General Assembly Resolutions and the UNCTAD Roadmap. ${ }^{1}$ My contribution examines two of the Basic Principles on Sovereign Debt Restructuring Process adopted by the UN General

* Associate Professor of Law, Cornell University Law School, OL53@cornell.edu.

1. See Juan Pablo Bohoslavsky \& Matthias Goldmann, An Incremental Approach to Sovereign Debt Restructuring: Sovereign Debt Sustainability as a Principle of International Law, in this issue. 
Assembly: legitimacy and impartiality. ${ }^{2}$ It goes beyond the necessarily brief formulations of the GA-approved Principles themselves to ask several key background questions: How can these concepts be understood and why do they deserve greater consideration in future debt restructurings? To what degree are these principles already present in parallel domestic and transnational regimes in ways that might be useful for thinking through sovereign debt restructuring itself? Drawing from a recently published longer article, I contend that actors involved in sovereign debt should more deliberately attend to these principles in the future in order to improve restructuring outcomes and garner the stable and long-term adherence of global stakeholders. ${ }^{3}$

This paper will first point out the possible instrumental value of adhering to these principles, particularly in helping to minimize the disruption inherent to debt restructurings. It will then introduce more fully the concepts of legitimacy and impartiality, laying out different schools of thought on the characteristics of legitimate and impartial orders and briefly highlighting how these elements could inform current practice. Finally, it considers how national and transnational institutions analogous to debt restructuring have attempted to meet these standards, focusing on domestic insolvency procedures and investment treaty arbitration. This Essay concludes that, despite the variation in their institutional manifestations, both legitimacy and impartiality are cognizable as foundational principles for future restructurings. While complete attentiveness to all of these features might not be pragmatically feasible, the UN General Assembly Resolutions and the UNCTAD Roadmap are right to emphasize the centrality of these principles for the sovereign debt regime going forward.

\section{THE INSTRUMENTAL VALUE OF LEGITIMACY AND IMPARTIALITY}

While many global stakeholders no doubt consider legitimacy and impartiality to be important values or goals in their own right, not everyone will necessarily subscribe to this view. Why would it matter, on the ground, whether a sovereign state's debt restructuring is considered legitimate or impartial? What might perceptions of legitimacy or impartiality do for any given sovereign debt restructuring, such that these concepts deserve inclusion in an international statement of principles on the topic?

It is clear that a restructuring can be a fairly traumatic economic, social, and political event in the life of a country. While it should ideally offer financial relief in the form of extended payment schedules or a debt writedown, the process also can entail a fiscal consolidation that results in cuts to government programs and other austerity measures. Setting aside for now the

2. UN General Assembly Resolution 69/319 of 10 September 2015, principles 4 and 7.

3. This contribution is based on and excerpts a much more extensive article recently published, Odette Lienau, The Challenge of Legitimacy in Sovereign Debt Restructuring, 57 HARV. INT'L L. J. 151-214 (Winter 2016). The longer piece extends the themes outlined here, applies them to historical debt practices and recent policy proposals, and considers the political tensions and distributional ramifications implicated in the discussion. I thank the guest editors of this YJIL Online issue for inviting me to contribute to this symposium, the YJIL Online editors for their excellent work on this essay, and the editors of the Harvard International Law Journal for their work on the earlier article. 
question of when such measures can become counterproductive, these policies often have significant domestic distributional ramifications, and the resulting anger may erupt in economically and politically disruptive ways. ${ }^{4}$ While entirely understandable, this second-order disruption can add to and extend the distress and sacrifice already generated by the restructuring itself.

How do legitimacy and impartiality play into this dynamic? Understanding impartiality as a component of legitimacy for now, perhaps the unique feature of institutions or rules that are considered legitimate is their ability to encourage voluntary compliance - to command a higher degree of support or acquiescence than might otherwise exist in the absence of coercion or self-interest. ${ }^{5}$ A procedure perceived to be more legitimate and impartial could thus encourage a greater willingness on the part of domestic groups to engage in consensual restructuring processes and then implement the resulting agreements with relative equanimity, thereby minimizing the second-order disruptions that can accompany a restructuring. Of course, this is hardly to deny that the anger arising out of debt restructuring is frequently justified, and that it can direct attention to important power imbalances both domestically and internationally. But if a consensual debt workout frequently is the right choice, then we should strive to identify mechanisms that restructure debt in a smooth, efficient, and minimally disruptive manner. And, of course, this instrumental value of legitimacy only supports the inherent value - recognized by many - of institutions that enable individuals and groups to comply with agreements as a result of considered choice rather than perceived duress or coercion.

All that said, a number of tensions and difficulties immediately emerge with an explicit focus on legitimacy and impartiality, particularly given that the concepts can mean different things to different people. Claiming legitimacy or impartiality on behalf of a particular institution, mechanism, rule, or process is a fraught exercise, as the content of these terms can be difficult to pin down. Indeed, "legitimacy speak" has been soundly criticized by important international legal scholars for its indeterminacy and lack of substance. ${ }^{6}$ Applying such conceptually slippery terms to the complex world of sovereign debt is no easy task.

The goal of the remainder of this contribution, then, is relatively circumscribed. It does not aim to formulate comprehensive or universal typologies of legitimacy and impartiality applicable across all arenas. ${ }^{7}$ Rather,

4. For an overview of possible distributional ramifications resulting from a decision to restructure (or the decision to delay restructuring), see Odette Lienau, The Longer-Term Consequences of Sovereign Debt Restructuring, in Sovereign DeBT MANAGEMENT 85, 89-90 (Lee Buchheit \& Rosa Lastra eds., 2014). For a discussion of both the practical problems with austerity measures and their intellectual history, see MARK BLYTH, AUSTERITY: THE HISTORY OF A DANGEROUS IDEA (2013).

5. See discussion infra, Part I.A.

6. James Crawford, The Problems of Legitimacy-Speak, 98 ASIL Proc. 271, 271 (2004) (noting the "fuzziness and indeterminacy" of the term); see also Martti Koskenniemi, Miserable Comforters: International Relations as New Natural Law, 15 EUR. J. INT’L REL. 395, 409 (2009) (suggesting that "[1]egitimacy is not about normative substance .... Its point is to avoid such substance but nonetheless to uphold a semblance of substance"). .

7. Indeed, understandings of legitimacy are necessarily variable and historically grounded. For a study of how shifts in conceptions of legitimacy ground systemic change in international society, see IAN CLARK, LEGITIMACY IN INTERNATIONAL SOCIETY (2005). Joseph Weiler suggests that forms of international lawmaking, including the legitimacy arguments with which they are associated, are best 
it presents a preliminary working understanding of institutional features that might enhance the perception that debt restructuring practices are more (or less) legitimate and impartial in the current, complex global context. The final elements ultimately incorporated into future debt restructurings are of course matters to be negotiated among key global stakeholders, involving decisionmaking that necessarily attends to the broader goals of pragmatic feasibility, timeliness, and cost effectiveness.

\section{BASICS AND THE BROAD AUDIENCE FOR LEGITIMACY}

As hinted at above, at the most general level, a rule, mechanism, norm, or institution can be understood as legitimate if it is considered worthy of voluntary compliance and/or support. If a rule or mechanism is perceived as legitimate, then approval and compliance result at least in part from that assessment, rather than from coercion, habit, self-interest, or other possible reasons for action. ${ }^{8}$ Part of the special virtue or power of a legitimate rule thus lies in its capacity to coordinate preferences and decisions effectively even in the absence of other bases for action. This quality becomes especially important in the international arena-including for a globally supported debt workout - where no supranational authority with broadly accepted powers of coercion exists. As discussed more fully below, legitimacy may derive from the initial source of, ongoing process of, or ultimate substantive outcome resulting from a rule, mechanism, or institution, or from some combination of these three basic components.

\section{A. The Broad Audience for Assessing Legitimacy}

The importance of legitimacy as a basis for action has long been recognized in the social sciences and in legal studies. For example, Max Weber formulated a definition relevant for sociological theory to the effect that "a norm or institutional arrangement is legitimate if, as a matter of fact, it finds the approval of those who are supposed to live in this group." "Thomas Franck proposed a definition of legitimacy intended for international law and international relations, initially formulated to apply among states, as "a property of a rule or rule-making institution which itself exerts a pull toward compliance on those addressed normatively because those addressed believe that the rule or institution has come into being and operates in accordance with generally accepted principles of right process." 10 In the last several decades, questions of the legitimacy of global governance have become even more central in both academic and policy writing, and scholars and activists have

understood not as periodization but rather, drawing from geology, as stratification, in which sediments of past practices continue into the present. Joseph H. H.Weiler, The Geology of International LawGovernance, Democracy and Legitimacy, 64 ZAÖRV 547 (2004).

8. See, e.g., Christopher A. Thomas, The Uses and Abuses of Legitimacy in International Law, 34 OXFORD J. LEGAL STUD. 729 (2014).

9. MAX Weber, ECONOMY AND SOCIETY: AN OUTLine OF INTERPRETIVE SOCIOLOGY, as quoted (and translated) in Lukas H. Meyer \& Pranay Sanklecha, Introduction to Lukas H. Meyer, Legitimacy, Justice, and Public International Law (Cambridge University Press, 2009), 2.

10. ThOMAS Franck, The POWER OF Legitimacy AMONG NATIONS 24 (1990),. 
built upon and extended these themes. ${ }^{11}$ In one recent influential article, Allen Buchanan and Robert Keohane emphasize that the concept of legitimacy appeals to a "common capacity to be moved by what might be called normative reasons," and a "complex belief" that institutions may deserve support even if they fail to maximize self-interest and also fall short of (inevitably divergent) understandings of perfect justice. ${ }^{12}$

Central to these formulations is the idea that conforming action is motivated by the legitimacy of the mechanism itself through the belief or normative approval of the relevant audience. This interactive element leads to several preliminary implications. First, the relevant audience for legitimacy purposes in any sovereign debt restructuring should ideally include all those actually affected by the restructuring - that is, all those who live in the group to which the applicable processes, mechanisms, or decisions apply. This audience encompasses those without the position or power to enact or enforce rules, including citizens of countries undergoing a debt workout and small creditors who may have had minimal voice in the restructuring process. This definition of the relevant audience accords with one of the general goals of establishing a legitimate order, which is to encourage voluntary adherence by all relevant actors to the extent possible. This includes those individuals who may not have participated in either institutional design or particular restructuring processes, but who are nonetheless affected by their outcomes and who may therefore object to or impede implementation once decisions are made. The contention that a broad audience is relevant for assessing legitimacy does not mean that universal acceptance or adherence is required. For example, it is possible that certain actors will remain intransigent even in the face of a rule, institution, or outcome generally determined to be legitimate, in which case opposition might well be considered illegitimate. However, care should be taken when drawing these lines, particularly given the political import and distributional impact of claims about legitimacy or illegitimacy.

\section{B. Components of Legitimacy: Source, Process, and Outcome}

The preceding discussion should make clear that determining one limited set of indicators for legitimacy would be overly simplistic, given the breadth and multiplicity of its audience. Indeed, for any context and historical moment, legitimacy can be understood as "a composite of, and an accommodation between, a number of other norms, both procedural and substantive." ${ }^{33}$ This section thus lays out key features that frequently play a part in claims about legitimacy. Drawing from multiple schools of thought, there are three main approaches to legitimation. ${ }^{14}$ These, in turn, correspond to three questions

11. See, among others, JUtTA BRUNNÉE \&STEPHEN TOOPE, LEGITIMACY AND LEgALity IN INTERNATIONAL LAW (2010); MEYER, supra note 12; and RÜDIGER WOLFRUM \& VOLKER RÖBEN, LEGITIMACY IN INTERNATIONAL LAW (2008)

12. Allen Buchanan \& Robert Keohane, The Legitimacy of Global Governance Institutions, in Rüdiger Wolfrum \&Volker Röben, supra note 12, at 30, 31-32.

13. Clark, supra note 8, at 207.

14. This organizational framework and language is selected to be relatively simple, colloquial, and appropriate for the issue area. For related typologies applied in different applications, see Vivien A. Schmidt, Democracy and Legitimacy in the European Union Revisited: Input, Output and 'Throughput', 
relevant for thinking through legitimacy in sovereign debt restructuring:

Source Legitimacy: First, how are debt restructuring processes, or particular rules associated with these processes, to be formulated - and by whom? A rule, mechanism, or institution may be considered more legitimate if its source and initial establishment satisfy the key values of the legitimating group.

Process Legitimacy: Second, are the processes by which a sovereign debt restructuring unfolds in line with broadly accepted procedural standards? The ongoing processes or procedures through which an institution works or a rule is implemented, as distinct from either the initial development of the rule or its results, may confer an additional and separate layer of legitimacy.

Outcome or Substantive Legitimacy: Finally, is a sovereign debt restructuring able to generate successful outcomes, understood in terms of substantive goals? Aside from considerations on the source or process front, an institution or rule may be considered legitimate if it generates desired outcomes. Key follow-up questions here include how to define and determine positive substantive outcomes, and also who should make this assessment.

Again, given the large and diverse audience for legitimacy, different groups will likely put more or less weight on particular levels or understandings of the concept. Although this oversimplifies somewhat, a debt-restructuring regime that aims to incorporate key features drawn from each level may have the best chance of being considered more legitimate by a broader audience. Of course, there can be tensions between particular legitimizing characteristicsfor example, maximum efficiency and broad participation - which would have to be balanced at both a general institutional level and within any particular debt workout situation. To begin with, however, this section offers an overview of which elements actually merit consideration by sovereign debt negotiators attentive to legitimacy issues.

\section{Source (or Establishment) Legitimacy}

One central understanding of legitimacy involves a focus on how a practice, rule, mechanism, or rule-giving institution is originally established. To the extent that this initial establishment falls in line with core values of the applicable audience or community, the norm or regime may be considered more legitimate. There are several possible ways to think through the legitimacy of debt restructuring practices at the source level.

The classic legitimating mode in international law and global relations is state consent. In this traditional view, states are considered the key creators of international law as well as their primary (and perhaps only) subjects. Explicit state consent, for example in a treaty is necessary and in some cases sufficient for source legitimacy under this view. Although this approach has been soundly criticized, in particular for failing to consider the legitimacy or illegitimacy of states themselves, it remains a widely acknowledged standard for source legitimacy in international law and global affairs. ${ }^{15}$

61 POL. STUD. 2 (2013); and Thomas, supra note 9.

15. For criticisms of the state consent model, see Buchanan \& Keohane, supra note 12, at 35- 
Democratic legitimation is a central legitimating framework in many nations, and is increasingly discussed at the global level as well. Here, the legitimacy of a rule, mechanism, or governance body is only achieved if it is grounded in the support and input (either directly or through representatives) of the underlying people. Such support, perhaps offered through majoritarian electoral institutions or other mechanisms, can legitimately bind even those not in favor of a particular rule. One vision of global democracy might characterize all inhabitants of the globe as citizens, and attempt to aggregate their voices directly through a mechanism that bypasses states and other intermediaries. However, this latter approach is far from workable at this point, even were it normatively desirable. A general attentiveness to the voices of individuals (rather than only to states or other group entities), however, may offer some element of democratic legitimacy to sovereign debt restructurings.

Participatory legitimation would aim for the participation of important (and potentially divergent) groups in sovereign debt restructurings. Less demanding than strict democratic legitimation, this approach does not narrowly specify the identity of the stakeholders or the mechanism of participation and control. However, it does mandate that a good faith effort be made to identify and involve an appropriately broad, or at least broadly representative, array of stakeholders through meaningful participatory mechanisms. ${ }^{16}$ Central to this legitimating element is the principle that participatory mechanisms should be impartial, not favoring or biased toward one particular group.

Expertise or authority represents a final form of source legitimacy. If accepted authority figures play central roles in developing rules or institutions, then the rules may be considered more legitimate. Classic forms of authoritybased source legitimacy involve religious or moral codes; scientific, technical, or academic expertise; and traditional government.

\section{Process (or Implementation) Legitimacy}

A second level of legitimacy, which may complement other types, can be understood as process legitimacy. Once a restructuring mechanism is actually established, the nature of its implementation and ongoing functioning may also affect perceptions of legitimacy. In particular, processes that adhere to certain procedural standards, including those that guard impartiality (discussed as a

36; Armin von Bogdandy \& Matthias Goldmann, Sovereign Debt Restructurings as Exercises of International Public Authority, in CARLos Esposito, YUEFEN LI \& JUAN PABLo Bohoslavsky, SOVEREIGN FinANCING AND INTERNATIONAL LAW: THE UNCTAD PRINCIPLES ON RESPONSIBLE SOVEREIGN LENDING AND BORROwING 48 (eds., 2014). However, Benedict Kingsbury highlights the distributional ramifications of a commitment to sovereign state equality and state consent, noting that "a decline in the traditional sovereign system weakens the relationship of mutual containment between sovereignty and inequality." Benedict Kingsbury, Sovereignty and Inequality, in INEQUALITY, GlobalizATION, AND WORLD POlitics, 92 (Andrew Hurrell \& Ngaire Woods, eds., 1999). And as Joseph Weiler points out, even those norms grounded in earlier ideological periods may still have some resonance today. Weiler, supra note 7.

16. Along these lines, Terence Halliday highlights the potential importance of what he calls a representative basis for the legitimacy of international organizations, which involves "persuading prospective audiences that future products of an organization have been formulated by actors that share their interests or attributes.” Terence C. Halliday, Legitimacy, Technology, and Leverage: The Building Blocks of Insolvency Architecture in the Decade Past and the Decade Ahead, 32 BROOKLYN J. OF INT'L L. 1084 (2006-2007). 
separate principle below), may grant them greater legitimacy in the eyes of key constituents. One caveat to keep in mind in terms of process, however, is that certain generally desirable elements-for example, broad participation and transparency - may be less feasible in specific emergency or crisis management situations. As such, future discussions on sovereign debt restructuring might include a consideration of whether modified procedures are appropriate for such situations, and a mechanism for delineating when the application of a modified process would be warranted.

In line with ideas of procedural fairness, the ongoing participation and input of affected individuals and groups, particularly before key decisions are made, could enhance the perceived legitimacy of sovereign debt restructurings. Such participation might work through either direct access or representative structures. In order to ensure the presence of a broad array of voices, participatory processes can allow for input from third parties (such as NGOs) acting as amici curiae. More specifically, this could involve the opportunity to be heard or provide comments on possible restructuring plans, the allowance of debt claims, and other issues. The notice and comment procedures present in American administrative law, along with the claim allowance procedure in some domestic insolvency proceedings, could provide guidance on this front. And the mechanisms for ongoing participation would ideally strive to be impartial, not inappropriately privileging one or another viewpoint.

One exception to this general preference for impartial procedures involves the idea of country ownership, which would allow a special attentiveness to the concerns of the sovereign debtor undergoing a restructuring. "Ownership" of adjustment programs, particularly those mandated by International Financial Institutions (IFIs), has been considered an important element of process legitimacy in current sovereign debt restructuring practice and would be relevant going forward. This comports with ongoing commitments to self-determination and sovereign control, which remain overarching principles in international law. Like process legitimacy itself, country ownership also can have instrumental value. As pointed out in a study of the challenges in reconciling country ownership with conditionality, "program ownership, by reflecting a firm commitment from the government, implies that the difficult policy measures . . . are more likely to be implemented." $" 17$

Comprehensiveness and full involvement present a particular challenge for any governance system, especially at the global level, where disparate parties often fail to take collective action. This certainly is the case in sovereign debt issues, and scholars and policymakers have identified lack of creditor cooperation and forum fragmentation as central problems. ${ }^{18}$ The

17. Mohsin S. Khan \& Sunil Sharma, Reconciling Conditionality and Country Ownership, 39 FIN. \& DEV. no. 2 (June 2002); see also J.H. Johnson, Borrower Ownership of Adjustment Programs and the Political Economy of Reform, World Bank Discussion Paper No. 199 (1992).

18. See, for example, UNCTAD, Debt Workout Mechanism Framing Paper, 2 September http://www.unctad.info/upload/Framing\%20Paper\%2027\%20August_finalwithlogo.pdf. Framing Document. See also UNCTAD, Sovereign Debt Workouts: Going Forward. Roadmap and Guide (2015) at http://www.unctad.info/en/Debt-Portal. 
formulation and successful implementation of procedures that address these problems would thus be especially relevant to perceptions of process legitimacy in future sovereign debt restructurings. The goal here is to ensure not just the opportunity to participate, but also to ensure that all relevant parties in fact $d o$ participate to the extent possible. This element of comprehensiveness is likely to have an impact on outcome legitimacy as well, as full involvement by relevant parties is more likely to result in a final resolution of debt claims, a return to economic growth, and an enhanced capacity to access capital markets at better rates.

Transparency has value in and of itself and also supports many other elements associated with process legitimacy. ${ }^{19}$ To begin with, it is a precondition for ongoing participation and honest communication, as it allows for the dissemination of information and restructuring proposals about which parties may have views. Furthermore, it allows stakeholders to determine whether an institution or mechanism functions in line with its goals and is likely to result in positive outcomes. It is thus unsurprising that agencies involved in global governance, including the IMF and the World Bank, have tried to become more transparent, albeit sometimes in response to significant external pressure.

Reason-giving, that is, clarifying the reasons for particular decisions, includes providing the analytical and informational or evidentiary foundations underpinning final outcomes. ${ }^{20}$ Closely related to transparency, reason-giving helps to ensure that the views of various stakeholders have in fact been taken into account, and that improper bases for decision-making have not impacted the outcome.

Efficiency of procedures also constitutes one element of process or implementation legitimacy. Parties will be more likely to accept an institution, rule, or mechanism if the procedures with which it is associated do not divert undue resources, time, and attention away from the pursuit of other important goals. This element also implicates outcome legitimacy, as even generally positive results, such as a return to debt sustainability or the achievement of satisfactory levels of socio-economic rights, will be undermined if they are not achieved in a reasonably timely fashion. ${ }^{21}$

19. Matthias Goldmann, "Good Faith and Transparency in Sovereign Debt Workouts," Paper Prepared for the Second Session of the UNCTAD Working Group on a Debt Workout Mechanism, 23 January 2014. See especially 17-23. In addition, it has been highlighted as a general principle of Global Administrative Law and an important emerging feature of international law and global governance. See Benedict Kingsbury, Nico Krisch, \& Richard B. Stewart, "The Emergence of Global Administrative Law," Law \& Contemporary Problems, vol. 68, 15-61 (2005), 37-39; Andrea Bianchi and Anne Peters, Transparency in International Law (Cambridge University Press, 2013); Alexandru Grigorescu, "Transparency of Intergovernmental Organizations," International Studies Quarterly, vol. 51 (2007).

20. The importance of reason-giving in an international adjudicatory setting is accepted in, for example, the statute of the International Court of Justice, which states in article 56(1) that "[t]he judgment shall state the reasons on which it is based." Statute of the I.C.J., art. 56(1). Armin von Bogdandy and Ingo Venzke note that reason-giving permits "decisions to be discursively embedded and to be critiqued before the court of public opinion." Armin von Bogdandy \& Ingo Venzke, On the Democratic Legitimation of International Lawmaking, 12 GERMAN L. J. 1341, 1343 (2011).

21. The phrasing of Principle 15 of the UNCTAD Principles on Promoting Responsible Sovereign Lending and Borrowing, which requires that any restructuring "should be undertaken promptly, efficiently, and fairly," very explicitly incorporates this element. UNCTAD, Principles on Promoting Responsible Sovereign Lending and Borrowing, 10 January 2012. Available at: 
Finally, the possibility of review by an external entity of the procedures and decisions implicated in a debt restructuring may help to support fair and impartial processes as well as outcome legitimacy. Improper biases or procedural irregularities could be corrected or compensated for, responding to those dissatisfied by particular outcomes or at least ensuring that their specific concerns have been heard. Perhaps more important, the possibility of review can heighten internal monitoring, encouraging parties and decision makers to more closely scrutinize their own actions, and thus magnifying the impact of all of the other elements associated with process legitimacy just discussed. In addition, external review may help to ensure that restructuring outcomes comply with central principles and objectives.

\section{Outcome or Substantive Legitimacy}

A final set of standards relevant to the perceived legitimacy of a restructuring would involve its ability to generate successful outcomes, understood in terms of substantive goals. The capacity of a rule, institution, or mechanism to produce results that satisfy the needs or desires of constituents will almost always confer an important degree of legitimacy. ${ }^{22}$ While it is unlikely that any institution or rule could produce absolutely optimal outcomes, however defined, the restructuring in question would still need to meet a minimum threshold of success to be acceptable. ${ }^{23}$ The type of outcome that characterizes 'success' necessarily varies across issue area, but several possibilities are especially relevant for a sovereign debt restructuring.

Positive economic and financial results will feature importantly in the perceived outcome legitimacy of any debt workout. From the sovereign debtor perspective, a successful restructuring outcome would involve a return to debt sustainability and economic growth, ${ }^{24}$ and perhaps also an eventual improvement in creditworthiness and a return to capital market access. From a creditor perspective, it would involve reasonable recovery on an investment. Outcome considerations calibrated according to more specific standards-for instance, approaches associated with "global justice" advocated by certain groups - may consider other economic results to be desirable, such as global redistribution of wealth. Asset recovery may also feature as a desirable financial outcome and could partially relieve the need for creditor losses or harsh austerity measures.

Basic human impact in the debtor country would also serve as a basis for evaluating any restructuring. Under this broad rubric, alternative approaches might focus on a simple concern for basic well-being or on the active improvement of outcomes for individuals in terms of a more expansive

http://www.unctad.info/upload/Debt\%20Portal/Principles\%20drafts/SLB_Principles_English_Doha_2204-2012.pdf.

22. In the EU context, this is called "output legitimacy" by Fritz Scharpf, Vivien Schmidt, and others. Fritz Scharpf, Governing in Europe (Oxford University Press, 1999); Vivien Schmidt, n. 14.

23. Buchanan and Keohane refer to this more instrumental perspective as a concern with "comparative benefit" as compared to other possible institutions (or presumably as compared to the absence of an institution, if that is the alternative). Buchanan and Keohane, n. 12, 46-47.

24. On the concept of debt sustainability, see Bohoslavsky and Goldmann, note 1. 
conception of human rights. In addition, there may be questions as to which standards are sufficiently established and internationally appropriate to ground outcome judgments. ${ }^{25}$ Adherence to other substantive principles or doctrines may also be relevant to judging outcomes. These might include unclean hands, unconscionability, fraudulent transfer, and concerns about governmental responsiveness to and responsibility for underlying populations.

Consistency across cases provides one final feature that could be associated with perceptions of outcome legitimacy. Such consistency would enhance the predictability and stability of markets, a benefit for both sovereign borrowers and investors alike. Forum fragmentation and variations in (and possibly inconsistent interpretations of) the laws, principles, and procedures that apply to debt restructurings currently undermine this consistency. That said, as a cautionary note, it is important to keep in mind that the consistent application of a problematic practice-perhaps leading to uniformly substandard results - is not necessarily favorable in and of itself. As such, consistency perhaps should be understood as a subsidiary element. In addition, given the political, social, and economic variability that can exist among sovereign debt situations, any restructuring should likely not focus on consistency at the expense of attentiveness to the situation at hand.

\section{THE IMPORTANCE OF IMPARTIALITY}

A central companion to and support for legitimacy in the international arena is the ideal of impartiality. Indeed, I consider impartiality to be a core factor underpinning the more comprehensive category of legitimacy, as well as a valuable principle in its own right. Particularly in the context of decisionmaking bodies such as tribunals, impartiality and independence have been called "the most important determinant of political legitimacy at the international level," with legitimacy requiring that such bodies "be sufficiently independent of the powerful actors that dominate the political sphere to take less powerful and minority interests into consideration." ${ }^{26}$ Thus, although impartiality has already been implicated in several of the legitimating features mentioned above, it deserves further explication. I organize the bulk of this brief discussion into a consideration of institutional impartiality, actor impartiality, and what I call informational impartiality.

\section{A. Basic Definition}

Generally speaking, impartiality can be understood as a way of thinking, decision-making or acting that is free of bias or preference and that is grounded in independence and objectivity. ${ }^{27}$ It is an essential component of

25. Along these lines, Buchanan and Keohane refer to "minimal moral acceptability" and a "non-violation of human rights." Buchanan and Keohane, n. 12, 46.

26. Eyal Benvenisti \& George W. Downs, "Prospects for the Increased Independence of International Tribunals," German Law Journal, vol. 12, no. 5, 1057-1082 (2011), 1058.

27. Steven Ratner, for example, describes impartiality as "a way that individuals and institutions decide and act, one based on disinterestedness, consistency, and fairness and not merely personal motives." Steven R. Ratner, "Do international organizations play favorites? An impartialist account," in Meyer, ed., n. 11, 128. 
colloquial understandings of justice and fairness. Impartiality may be compromised by biases or preferences grounded in national, regional, political, ideological, or personal affiliation. Although these biases are perhaps most easily cognizable in how individuals think and act, they can also impact how institutions or institutionalized practices are established and can therefore affect their goals and operating processes.

As a central underpinning of legitimacy, impartiality plays a role not only through actual objectivity and independence, but also through perceptions and acknowledgment of objectivity and independence by relevant constituencies. In other words, the interactive element of legitimacy contemplated above translates to impartiality as well. ${ }^{28}$ Although complete impartiality (like universal legitimacy) is perhaps impossible to achieve, impartiality remains an important factor to consider in any sovereign debt workout.

\section{B. Elements of Impartiality}

To maximize institutional impartiality, any sovereign debt restructuring should be organized to avoid systematic bias in favor of one or another interested group. One key sub-feature that could support this larger goal is institutional independence: the organizations and mechanisms involved in a workout ideally would minimize their affiliation with groups or actors that might be affected by the restructuring processes. This separation might include attentiveness to financial independence, personnel independence, and perhaps physical independence (such as through geographic location in a neutral setting). This would be especially important to the extent that any restructuring regime eventually involves a more permanent organization. Transparencyenhancing and review procedures, discussed above, could enhance this type of impartiality by making an institution's inner workings more visible to interested parties, and by serving as a check on those procedures.

To the extent that any debt restructuring involves a central role for third party decision-makers, whether serving as mediators, facilitators, or adjudicators, it would be important to ensure actor impartiality as well. Perhaps the central feature of actor impartiality involves independence, or ensuring that decision makers and mediators remain independent of the negotiating parties, both individually and as a group (in multi-party decisionmaking situations). ${ }^{29}$ As part of actor impartiality, decision maker disclosure requirements may be appropriate. Furthermore, requiring decision makers to specify the rationale for any conclusion through processes of reasoned judgment can help to support actor impartiality. This practice ensures that decision makers clarify for themselves that the underlying analysis is impartial, and also allows other actors to provide a check on any bias that may exist. Finally, the use of multi-person decision-making may help to mitigate actor

28. The desirability of drawing from a plurality of traditions and standards, discussed in the context of legitimacy above, is applicable to the principle of impartiality as well, given that it will be judged by the same multiple audiences.

29. This gives rise to the expectation or requirement, in many domestic and international judicial settings, of judicial decision-makers recusing themselves from cases in which they may be biased or be perceived to be biased. 
bias, as decisions will have to be discussed and justified. This depends, of course, on a balanced initial selection of individuals, as well as on a commitment on the part of these individuals to think and act as impartially as possible.

A third dimension of impartiality includes what I call informational impartiality, or the impartiality of informational inputs. Although information may be presented as objective, such inputs can embed biases or preferences in subtle ways. This can affect both a restructuring outcome and also the final opinion or assessment of its success. Indicators constitute one central informational input into any sovereign debt restructuring, and recent work has highlighted the economic and legal aspects of the use of indicators in a potential debt workout mechanism. ${ }^{30}$ In addition, social science models, which predict the likely outcomes of restructurings and related domestic measures (in terms of GDP growth, social costs, and other metrics), can feature importantly in any sovereign debt decision. They may be used by debtors, creditors, and other decision makers to determine the ex ante feasibility of a particular restructuring plan, and in particular to determine the extent of relief necessary to return a debtor to sustainability. Although such models are no doubt presented in good faith, they can fail to characterize the situation fully and may thus favor one or another group in a debt crisis, even when relevant actors and institutions aim for independence and objectivity in their assessments. ${ }^{31}$ The question of which models and methodologies are appropriate, and of who should make this selection, can thus be quite controversial. As such, care should be taken to ensure that the selection and use of social science models reflects an understanding of their political character and distributional ramifications. ${ }^{32}$

\section{Foundations In DOMESTIC INSOLVENCY PRINCIPLES}

To what degree are elements of legitimacy and impartiality already incorporated into areas related to sovereign debt restructuring? In this and the following Sections, I look at two regimes with important parallels to sovereign debt in order to imagine how future workouts might incorporate features associated with these principles. In this section, I focus on domestic insolvency and debt restructuring institutions, primarily as interpreted through the United Nations Commission on International Trade Law ("UNCITRAL") Legislative

30. Michael Riegner, "Legal frameworks and general principles for indicators in sovereign debt restructuring," in this issue; Jasper Lukkezen and Hugo Romagossa, "Early warning indicators in a debt restructuring mechanism," UNCTAD Working Group Paper (2014).

31. In the first days of 2013, IMF chief economist Olivier Blanchard co-published a working paper (interpreted as a mea culpa) suggesting the organization had misjudged and underestimated the negative effect of austerity measures on growth in European countries during the crisis. See Olivier Blanchard and Daniel Leigh, "Growth Forecast Errors and Fiscal Multipliers," IMF Working Paper No. 13/1, 3 January 2013; Howard Schneider, "An Amazing Mea Culpa from the IMF's Chief Economist on Austerity," Washington Post online, 3 January 2013.

32. This insight is central to the discipline of international political economy. For volumes emphasizing the contingent and politically conditioned nature of economic models, see Jonathan Kirshner, ed., Monetary Orders: Ambiguous Economics, Ubiquitous Politics (Cornell University Press, 2003); Rawi Abdelal, Mark Blyth, and Craig Parsons, eds., Constructing the International Economy (Cornell University Press, 2010). 
Guide on Insolvency. I then consider rules covering two adjudicative bodies involved with investor-state arbitration.

While the development and study of comparative insolvency law as a standalone field is relatively recent, ${ }^{33}$ the last decades have seen an explosion of interest in promoting and harmonizing the rules and mechanisms governing insolvency. Perhaps the most comprehensive and successful effort to formulate both shared principles for insolvency and possible models for their implementation culminated in the UNCITRAL Legislative Guide on Insolvency, initially published in $2005 .{ }^{34}$ Given significant similarities with the sovereign debt situation, it is notable that features designed to promote legitimacy and impartiality play a central role in both UNCITRAL's collective effort to identify best practices as well as in domestic insolvency proceedings themselves.

\section{A. Legitimacy Concerns}

To begin with, the UNCITRAL guide itself was developed on the basis of representation and through the auspices of a working group attuned to source legitimacy concerns. ${ }^{35}$ This representation involved official and observer state delegations, international financial institutions, international governance organizations, and professional associations. Expert-based source legitimacy also derived from the involvement of these professional associations, along with the use of experts from practice, academia, policy, and other arenas in more ad hoc drafting sessions. General state consent to the process and to the product was offered through General Assembly Resolution 59/40, ${ }^{36}$ though of course the actual enactment and implementation of insolvency laws work through the national level.

Domestic insolvency proceedings tend to place considerable emphasis on process legitimacy and procedural fairness, including impartiality, which may be understood as a norm applicable to insolvency more generally and thus translatable to the global level as well. One of the key objectives of insolvency procedures, as laid out in the UNCITRAL Guide, is to provide for a "timely,

33. Particularly since the 1970 s, there has been serious attention paid to this field at the national level, with authoritative study groups and committees formulating principles and recommendations for modernizing bankruptcy/insolvency policy and legislation. See, for example, the Commission on the Bankruptcy Laws of the United States (1970, partially leading to the major 1978 reforms of federal bankruptcy legislation); Report of the Review Committee on Insolvency ('Cork Report,' 1982); Report of the Canadian Advisory Committee on Bankruptcy and Insolvency ('Colter Report', 1986); Australian Law Reform Commission's Report No. 45: General Insolvency Inquiry ('Harmer Report,' 1988).

34. The foundational text of the UNCITRAL Legislative Guide is available at http://www.uncitral.org/pdf/english/texts/insolven/05-80722_Ebook.pdf. For a fascinating overview of its developments, as well as the ways that global-local tensions can result in implementation gaps, see Terence C. Halliday and Bruce G. Carruthers, Bankrupt: Global Lawmaking and Systemic Financial Crisis (Stanford, 2009)

35. This attentiveness to legitimacy was deepened because of UNCITRAL's recognition that it had been brought into the process in part due to the legitimacy problems of other institutions, in particular the IMF and the World Bank (due to suspicion of their activities among some developing countries and their association with Washington, D.C.), INSOL and the IBA (primarily insolvency and legal practitioners, respectively, with professional biases and associated pecuniary interests); and the regional development banks. Halliday \& Carruthers, id., 128-129.

36. United Nations General Assembly, A/Res/59/40 (2 December 2004). 
efficient and impartial resolution of insolvency." ${ }^{37}$ The Guide further emphasizes the centrality of transparency, noting that enacted laws should "[e]nsure a transparent and predictable insolvency law that contains incentives for gathering and dispensing information." 38 In every jurisdiction, debtors can voluntarily commence insolvency proceedings, which presumably helps to encourage ownership of the process. To balance this debtor control, some jurisdictions require an eligibility determination before the insolvency mechanism is technically triggered and applicable standstill provisions, or stays on collection and litigation, are put in place. ${ }^{39}$ Broadening the range of participation, domestic insolvency proceedings ideally seek to provide fair process and a right to be heard for creditors whose claims will be determined and possibly curtailed. Given the large number of creditors involved in some insolvency proceedings, many national jurisdictions contemplate the use of committees as a mode of participation. However, the Guide notes that steps should be taken to ensure that such committees are truly representative and impartial as to the interests of its members, for example by disallowing the appointment of unduly partial creditors to a committee. ${ }^{40}$

In addition, comprehensiveness is central to perceptions of legitimacy in domestic insolvency systems. A distinctive feature of insolvency law is its recognition of a debtor's inability to pay creditors as a group, as opposed to just one particular creditor. Insolvency legislation thus deals with unsustainable debt on a collective basis. ${ }^{41}$ This collective element means that to an important degree creditors may be in tension with one another rather than only with the debtor. But creditors as a whole should gain from cooperation, as compared to a situation in which each seeks payment for itself but risks the prospect of complete nonpayment in the event of coming late to the game. As such, to the extent that creditors intend to make any claim on the debtor's assets, their participation in the process is required. This fact ensures a high degree of involvement, and is accompanied by procedures that allow for the full participation of interested creditors or creditor groups, at least through representation. In the words of Rosalind Mason, "insolvency law features the notion of collective impartiality ... [because] there is a moratorium on creditor action and proceedings and a consolidation of the conduct of litigation. Individual claims are addressed through the collective administration, which balances the disparate interests of the various parties." ${ }^{42}$

In terms of outcome, the UNCITRAL Guide, as well as most national insolvency procedures, sets a baseline of acceptable creditor recovery. The

37. Recommendation 1(e), at 14.

38. Recommendation $1(\mathrm{~g})$, at 14 .

39. There is also variation in the availability and strength of involuntary proceedings. In any case, given the special sovereignty and autonomy concerns at the sovereign debt level, these would not be relevant.

40. See, for example, UNCITRAL Guide Recommendation 131, at 204.

41. Thus creditors may conflict with one another, as well as the debtor. For one early overview, see Elizabeth Warren, "Bankruptcy Policy," University of Chicago Law Review, vol. 54, 775 (1987), esp. 780-789.

42. Rosalind Mason, Cross-Border Insolvency Law: Where Private International Law and Insolvency Law Meet," in Paul Omar, ed., International Insolvency Law: Themes and Perspectives (Ashgate, 2008), 32. 
first key objective of the Guide, namely achieving a balance between liquidation and reorganization, includes the provision that in any restructuring "creditors would not involuntarily receive less than in liquidation." "43 Given the non-applicability of financially liquidating a sovereign state, this is difficult to translate. However, it relates to the general requirement that creditors be treated in good faith, and that they not be required to accept a lower payout than is necessary for the debtor's recovery. On the debtor side, as a general matter, restructuring plans in insolvency proceedings should not be agreed to or confirmed (to the extent that court confirmation is required) unless they are likely to actually rehabilitate the debtor in question. ${ }^{44}$ Thus a restructuring plan considered to be "too little" for the debtor problems at issue would not be considered outcome-legitimate, and therefore likely should not be confirmed or agreed to under general insolvency principles.

Many states have ratified the major human rights conventions, which could be considered an element of outcome legitimacy (as well as binding international law). Indeed, the UNCITRAL Guide notes that, in determining whether a natural person debtor's assets should be excluded from creditor recovery, "consideration might need to be given to applicable human rights obligations" in order to "allow for the minimum necessary to preserve the personal rights of the debtor [and relevant family members] and allow the debtor to lead a productive life." 45 The more general implication could be that human rights should be protected regardless of how natural persons are situated in an insolvency - that is, regardless of whether individuals are situated as debtors themselves or are simply among those impacted by a sovereign state debtor's restructuring. ${ }^{46}$

\section{B. Impartiality in Insolvency}

While process legitimacy, with its implication of impartiality, is a core element of domestic insolvency proceedings, impartiality also features as a central and independent principle of insolvency in its own right. In terms of institutional impartiality, there is considerable variation among states in the organizational settings for insolvency proceedings. Civil law countries like France, for example, mandate significant court involvement for any major decision. At the other end of the spectrum, Australia advocates that debtors dealing with insolvency avoid court oversight to the extent possible. While the UNCITRAL Guide remains neutral, it does specify that "competent and

43. UNCITRAL Guide (2004), 14-15. Quoted in Halliday \& Carruthers, n. 34, 141.

44. In the U.S. Chapter 11 context, for example, a court may not confirm a reorganization plan unless it meets the requirement of feasibility, in that it is not likely to result in an eventual liquidation. See 11. U.S. $\$ 1129$.

45. UNCITRAL Guide, Part II, A, para. 19, at 80. Additional references to human rights along these lines may be found in Part III, A., paras. $19 \& 29$. Para. 19 notes that the rights of "a natural person debtor in insolvency proceedings may be affected by obligations under international and regional treaties such as the International Covenant on Civil and Political Rights and the European Convention on Human Rights."

46. Human impact more generally can be considered relevant in insolvency proceedings. For example, the U.S. Bankruptcy Code provides exceptions to the general rule that unsecured debts will be discharged in liquidation. However, even these exceptions may be excused if continued debt payment would constitute "undue hardship" for the debtor. See 11 U.S. Code $\$ 523(a)(8)$. 
independent" courts should be available as a neutral background institution.

Even greater focus is placed on actor impartiality, particularly given that the Guide contemplates (but does not mandate) the appointment of an "insolvency representative" such as a trustee, administrator, or judicial manager to oversee the proceedings. Any such individual must not only be knowledgeable but also have the attributes of "integrity, impartiality, and independence." " The Guide recommends that any insolvency law "require the disclosure of a conflict of interest, a lack of independence or circumstances that may lead to a conflict of interest or lack of independence" and also that this obligation "continue throughout the insolvency proceedings."

In short, domestic insolvency law, and particularly UNCITRAL's clarification of globally applicable and accepted insolvency law principles, emphasizes features associated with claims about legitimacy and impartiality. In so doing, these sources demonstrate a number of practices that might enhance the perceived legitimacy and impartiality of future debt restructurings at the sovereign level.

\section{EFFORTS TOWARD IMPARTIALITY AND LEGITIMACY IN INVESTOR TREATY ARBITRATION}

Investor treaty arbitration lends additional support for attending to characteristics associated with legitimacy and impartiality. Such arbitration, which may be incorporated into hard law instruments such as bilateral investment treaties or concession contracts, directly involves sovereign states and investors. By its nature such arbitration is ad hoc and not built upon systems of precedent, and some observers raise serious concerns about inconsistency, bias, and other problems. Even more troubling charges have been made that such arbitration may be systematically biased in favor of investor claimants. ${ }^{49}$ Nonetheless, certain procedural rules in these arbitrations

47. UNCITRAL Guide, Recommendation 115, at 188 .

48. UNCITRAL Guide, Recommendations $116 \& 117$, at 188. Less explicit attention is paid to informational impartiality in domestic insolvency proceedings. However, as part of general process requirements, parties to insolvency proceedings are often allowed to offer expert opinions and testimony to support their projections of the likelihood of success (or of the value of particular assets, etc.) and also challenge the claims made by opposing stakeholders (for example, of the likely effect of a plan or plan provisions).

49. Gus Van Harten, for example, suggests that "the system is flawed, above all because it submits the sovereign authority and budgets of states to formal control by adjudicators who may be suspected - because they are untenured and because only one class of parties can bring claims - of interpreting investment treaties broadly in order to expand the system's appeal to potential claimants and, in turn, their own prospects for future appointment." Van Harten acknowledges that certain arbitrators may develop reputations for fairness and balance, but suggests that there is nonetheless "an unreliable bias." Gus Van Harten, Investment Treaty Arbitration and Public Law (Oxford University Press, 2007), vii. See also Pia Eberhardt \& Cecilia Olivet, "Profiting from Injustice: How Law Firms, Arbitrators, and Financiers are Fuelling an Investment Arbitration Boom," (Corporate Europe Observatory and the Transnational Institute, Nov. 2012). UNCTAD has also highlighted concerns with the current investor-state dispute settlement regime and laid out advantages and disadvantages to five potential paths to reform. See UNCTAD, "Reform of Investor-State Dispute Settlement: In Search of a Roadmap," IIA Issues Note, June 2013; available at: http://unctad.org/en/PublicationsLibrary/webdiaepcb2013d4 en.pdf. For a response to critics and a defense of the basic contours of the current system, see Charles N. Brower \& Sadie Blanchard, "From 'Dealing in Virtue' to 'Profiting from Injustice': The Case Against 'Re-Stratification' of Investment Dispute Resolution," Harvard International Law Journal Online, vol. 55 (January 2014). 
offer insight into how characteristics designed to enhance legitimacy are broadly incorporated and acknowledged to be desirable, even in this controversial arena and even when not fully successful. Two sets of rules commonly used, and thus referred to in this section, are the International Centre for Settlement of Investment Disputes (ICSID) Rules and the UNCITRAL Rules.

\section{A. Impartiality}

To begin with, it is important to highlight that one of the central purported benefits of arbitration is that parties enjoy a greater degree of control over the proceedings than in a conventional judicial dispute resolution setting. As such, by design, there is a lower degree of institutional independence in both the ICSID and UNCITRAL Rules than in standard domestic court settings. For example, the parties pay the arbitrators directly and have significant control over the arbitral location. ${ }^{50}$

Still, some attention is paid to supporting process legitimacy through a degree of attentiveness to actor impartiality, particularly in the selection of arbitrators. ICSID rule 6(2) requires that all arbitrators sign a declaration of independence in advance of the first session that lists any factors that might compromise their impartiality. ${ }^{51}$ In addition, article 39 of the ICSID Convention specifies that the majority of arbitrators be citizens of states other than the claimant-investor's home state and the respondent state. Similarly, in the event that the parties are unable to arrange a panel independently, arbitrators appointed by the Chairman of ICSID's Administrative Council must not be nationals of either the state party or the home state of the claimantinvestor. $^{52}$ Finally, the default procedures for ICSID stipulate a three-person tribunal, with each party appointing one arbitrator and then agreeing on a third, who serves as the panel's president. ${ }^{53}$

The basic orientation is very similar under the UNCITRAL Rules. Both prospective and appointed arbitrators have an ongoing duty to disclose circumstances that may raise doubts as to their impartiality or independence. ${ }^{54}$ Although the UNCITRAL Rules do not specify nationality requirements for arbitrators, they do mandate that the appointing authority consider "the advisability of appointing an arbitrator of a nationality other than the nationalities of the parties." ${ }^{, 55}$ The UNCITRAL Rules also presume (but do not require) that three individuals will be appointed to the arbitration panel. Each

50. However, given the absence of a standing institution with full-time professional decisionmakers, there is arguably less of a risk that a longstanding and deep-seated institutional bias would develop.

51. ICSID Rule 6(2). Note that ICSID maintains a pre-screened Panel of Arbitrators considered to have sufficient expertise and professionalism to be appropriate. However, parties may select arbitrators that are not on this list and so additional safeguards of impartiality have been put in place.

52. ICSID Convention Art. 38.

53. ICSID Convention Art. 37(2)(b); ICSID Rule 3.

54. UNCITRAL Rev. Art. 11. An annex to the UNCITRAL Rules even provides model "Statements of Independence" that can be used by arbitrators.

55. UNCITRAL Art. 6(4). 
party appoints one arbitrator, and then the two initial appointees consult and jointly select a third. ${ }^{56}$

Commentators have charged that even these procedures fall short and that problems are more endemic. ${ }^{57}$ Critics note that, in any case, the parties have not followed the processes sufficiently to rid investor state dispute settlement of bias or the perception of bias. ${ }^{58}$ Nonetheless, these institutional features clearly are designed to promote the goal and general principle of impartiality. They therefore can provide a guideline - or perhaps a baseline - for thinking through elements that might support perceptions of impartiality in future sovereign debt restructurings.

\section{B. Legitimacy}

Although impartiality is in itself a core legitimating element in investorstate arbitration, other features mentioned in the conceptual discussion of legitimacy in Section 3 above are present as well. As just noted in the overview of impartiality and investor-state arbitration, party ownership and control-important elements in understandings of legitimacy-are especially central in investor-state arbitration. Given the limited number of parties generally involved, their equal participation is less of a problem than it might be in other settings. And, notably, a series of amendments to the ICSID Rules in 2006 aimed to improve the transparency and participatory element of proceedings even for non-parties. In particular, rule 37 makes possible submissions by "non-disputing parties" through amici curiae, rule 32 covers the possibility of making hearings open to the public, and rule 48 governs the publication of awards. ${ }^{59}$

In regard to efficiency, the ICSID Rules specify that a tribunal should be constituted "as soon as possible" and "with all possible dispatch" after an arbitration is requested, with a series of time frames for arbitrator appointments. ${ }^{60}$ The UNCITRAL Rules similarly note a time window for constituting the tribunal and appointing arbitrators, specifying that the appointing authority is required to make the election "as promptly as possible." ${ }^{61}$ However, under both processes there exists the possibility of manipulation and delay by the parties, particularly through the process of appointing (and objecting to) arbitrators. As such, the process ownership and

56. Parties may also agree on a sole arbitrator, or on the appointing authority for a sole arbitrator, with the Secretary General of the Permanent Court of Arbitration serving as the default in the event that the parties fail to reach agreement. UNCITRAL Art. 6.

57. Van Harten, n. 49; Eberhardt \& Olivet, n. 49.

58. One much remarked upon ICSID arbitration is that of Vivendi II, in which an ad hoc committee reviewing a tribunal's decision criticized one of the arbitrators for failing to disclose her board position at a bank holding shares in the claimant investor, but ultimately upheld the award. Compañia de Aguas del Aconquija S.A. and Vivendi Universal S.A. v. Argentine Republic (ICSID Case No. ARB/97/3) (Annulment Proceeding) (10 August 2010). See especially para. 231-232.

59. Jason Yackee and Jarrod Wong review these amendments in detail, and generally consider them to be "modest, incremental, and conservative." Jason W. Yackee \& Jarrod Wong, "The 2006 Procedural and Transparency-Related Amendments to the ICSID Arbitration Rules," in Yearbook on International Investment Law \& Policy, Karl. P. Sauvant, ed., ch. 6 (Oxford University Press, 2010).

60. See ICSID Convention Article 37(1); ICSID Rule 1.

61. UNCITRAL Art. 6(3). 
consent elements of investment treaty arbitration may undermine efficiency. ${ }^{62}$

As with domestic insolvency, the rules governing investor treaty arbitration do value several mechanisms associated with process legitimacy. Although this incorporation is neither complete nor entirely successful, it does indicate the degree to which these design elements are held in high regard and broadly utilized. It also offers more specific ideas for incorporating features associated with legitimacy claims into potential future sovereign debt restructurings.

\section{CONCLUSION}

This essay has suggested that attentiveness to the principles of legitimacy and impartiality may contribute to the instrumental success of any sovereign debt restructuring, and has highlighted institutional elements or practices often associated with these goals. An additional question can be raised as to whether these principles might have a further claim to special consideration, as part of emerging customary international law or general principles of law. Any determination along these lines is made difficult by the fact that legitimacy is a composite principle, constituted of multiple procedural and substantive norms, and perhaps lacks the necessary specificity to be a legal rule itself. ${ }^{63}$ Impartiality also is a multi-faceted ideal, though it links so deeply to understandings of legal rule that it may well constitute a general principle of international law in certain adjudicative settings. Regardless, both legitimacy and impartiality can be understood as background guiding principles in international and domestic legal regimes alike. As such, they can help to orient the formulation of more specific rules and decision-making procedures in sovereign debt restructuring going forward.

Of course, neither principle can be achieved perfectly in any institutional setting, particularly given the need to balance goals of political feasibility, timeliness, and cost effectiveness. And, pragmatically speaking, neither works on a binary basis - few institutions or practices are either perfectly legitimate and impartial or entirely illegitimate and partial. Given that compliance with each is a matter of degree, one goal in thinking through incremental improvements in sovereign debt restructuring could be to eventually incorporate as many features associated with legitimacy and impartiality as possible. This objective might ground negotiations to establish more rational, coherent, and broadly supported sovereign debt practices for the future.

62. For a brief description of delay tactics from a practitioner perspective, Stephen Jagusch \& Jeffrey Sullivan, "A Comparison of ICSID and UNCITRAL Arbitration: Areas of Divergence and Concern," in Claire Balchin, Liz Kyo-Hwa Chung, Asha Kaushal \& Michael Waibel, eds., The Backlash against Investment Arbitration: Perceptions and Reality, 79, 84-85 (Kluwer 2010). Note that this refers to a previous version of the UNCITRAL Rules, but the themes remain pertinent.

63. Customary international law, accepted in key international documents as one potential source of law (along with treaties and general legal principles), is identified through "evidence of a general practice accepted as law." The emergence of customary international law on a topic can be demonstrated by the existence of relevant state practice in conjunction with a sense of legal obligation (opinio juris) - the belief on the part of the acting state that the practice is required by law. ICJ Article $38(1)$. 